\title{
ANALISIS PERBEDAAN PENDAPATAN PETANI CABAI \\ KEMITRAAN INDOFOOD DENGAN PETANI GUREM DI KECAMATAN BALIK BUKIT, KABUPATEN LAMPUNG BARAT
}

\author{
${ }^{1}$ Buchori, ${ }^{2}$ Eko Yudi Prasetiyo, ${ }^{3}$ Tri Mardiono \\ STIE Lampung Timur \\ Email : buchori122@gmail.com
}

\begin{abstract}
FIDUSIA
Jurnal Ilmiah Keuangan dan Perbankan

ISSN Cetak : 2621-2439

ISSN Online : 2621-2447

Kata Kunci : Revenue Cost

Ratio, Kemitraan, Petani Cabai

\section{ABSTRACT}

The purpose of this research is to study whether there is a difference in the income of Indofood Chili Farmers and Gurem Farmers in Balik Bukit District, West Lampung Regency ". Data analysis was carried out using qualitative data analysis methods which were presented descriptively about farm performance analysis. Farming budgets and analysis of revenue and participation participation ( $\mathrm{R} / \mathrm{C}$ Ratio) to determine the level of farm efficiency of the Indofood and Gurem partnership chili partnership in Balik Bukit, Lampung West. Bukit Barat Lampung Regency "can be accepted. The average divergence value of 19092000, it shows the difference between partnership farmers and smallholders Rp. 19,092,000.

Tujuan penelitian ini adalah untuk mengetahui apakah ada Perbedaan Pendapatan Petani Cabai Kemitraan Indofood dengan Petani Gurem di Kecamatan Balik Bukit Kabupaten Lampung Barat?". Analisis data yang dilakukan meliputi metode analisis data kualitatif yang dipaparkan secara deskriptif pada analisis keragaan usahatani. metode analisis kuantitatif menggunakan analisis pendapatan usahatani dan analisis perbandingan penerimaan dan biaya (R/C Ratio) untuk mengetahui tingkat efisiensi usahatani komoditas cabai kemitraan Indofood dan gurem di Balik Bukit, Lampung Barat.Hasil penelitian menunjukan bahwa Ada perbedaan pendapatan antara petani cabai kemitraan Indofood dengan petani gurem di Kecamatan Balik Bukit Kabupaten Lampung Barat" dapat diterima. Nilai mean diference sebesar 19092000, hal tersebut menunjukan bahwa perbedaan pendapatan antara petani kemitraan dan petani gurem sebesar Rp. 19.092.000.
\end{abstract}

Kata Kunci : Revenue Cost Ratio, Kemitraan, Petani Cabai 


\section{PENDAHULUAN}

Kabupaten Lampung Barat merupakan sentra sayuran dan kabupaten dengan tingkat produktivitas cabai yang cukup tinggi di Provinsi Lampung tentunya tidak luput dari perhatian pemerintah daerah dalam meningkatkan dan mengatasi permasalahan yang dihadapi petani setempat, seperti tambahan bantuan biaya modal usaha tani, pengetahuan dan kemapuan atau skill tenaga kerja. Maksimalisasi lahan yang dinilai terlalu sempit disebabkan oleh pertubuhan penduduk dan pembangunan pesat menjadi sebab umum eksistensi munculnya petani gurem.

Permasalahan pada saluran distribusi komoditas cabai harus diperhatikan sebagai salah satu tindakan kontrol harga guna meningkatkan pendapatan petani cabai semisal di Balik Bukit, Lampung Barat yang memiliki akses barang menuju pasar yang tergolong jauh dan sulit, menjadi salah satu sebab panjangnya rantai distribusi dan alasan tingginya harga cabai dipasaran. Diantara berbagai komoditas pangan strategis, cabai merupakan komoditas yang memiliki pola distribusi paling panjang. Tingginya harga cabai tidak lain karena harus melalui rantai distribusi yang panjang.

Rantai pemasaran yang panjang dan melibatkan banyak pelaku pemasaran tanpa adanya batas harga yang diatur, menyebabkan harga cabai yang berlaku tidak stabil. Diantara berbagai komuditas pangan strategis, cabai merupakan komuditas yang memiliki pola distribusi paling panjang. Tingginya harga cabai tidak lain harus melalui rantai distribusi yang panjang. "dari petani ke tengkulak kecil, dari tengkulak kecil ke tengkulak besar itu di lapangan. Kalau dipasar, dari tengkulak besar ke pedagang besar, dari pedagang besar ke pedagang kecil yang siap dijual kekonsumen,

Akibat rantai yang panjang ini, maka perbedaan harga dari produsen ke konsumen adalah yang paling besar diantara komoditas lain. Saat ini pemerintah terutama pemerintah daerah memiliki target untuk memotong mata rantai distribusi serupa.

Penjualan dilakukan melalui pedagang (tengkulak) yang datang langsung kepada petani. Mekanisme harga yang diterapkan adalah mekanisme harga pasar. Jadi petani kadang untung kadang rugi, disebabkan karena kebijakan harga yang fluktuatif ini. Selain permasalahan rantai distribusi yang panjang, terdapat pula masalah lain yakni dari faktor cuaca yang sulit diprediksi, munculnya hama dan penyakit mempengaruhi hasil produksi tanaman cabai. Sehingga resiko dari produksi ini menyebabkan tingkat produksi cabai menurun sehingga penerimaan petani semakin kecil.

Perusahaan swasta tidak luput pula ambil peran dalam pemasaran agribisnis dengan menawarkan kerjasama untuk kegiatan produktif dalam bentuk kemitraan di sektor pertanian yang dianggap sangat penting sebagai program alternatif dalam rangka penigkatan pendapatan masyarakat.

Salah satu perusahaan kemitraan di Lampung Barat yang menarik minat penulis untuk diteliti adalah perusahaan kemitraan Indofood yang memliki saluran distribusi lebih 
efektif, yaitu hanya membutuhkan rantai distribusi tunggal saja yaitu tengkulak besar yang bertugas menampung dan menyortir kualitas dan varietas cabai sebelum diterima oleh perusahaan mitra. Selain dari itu perusahaan Indofood menawarkan perjanjian kontrak harga yang dapat menjaga kestabilan harga jual cabai kemitraan Indofood.

Kesepakatan yang diberikan perusahaan kemitraan Indofood dinilai telah memberikan dampak untuk petani cabai di Kecamatan Balik Bukit, Lampung Barat dalam menstabilkan harga jual cabai dengan pola rantai distribusi tunggal yang berbeda dengan petani gurem setempat yang terpaksa mengikuti alur distribusi yang panjang tentunya berlaku juga di Kecamatan Balik Bukit, Lampung Barat. Sejarah berdirinya kemitraan indofood di Kecamatan Balik Bukit Kabupaten Lampung Barat tahun 2016, yang merupakan pusat dari kemitraan indofood yang ada di sumatra.

Petani di Kecamatan Balik Bukit sendiri dapat digolongkan ke dalam dua jenis yaitu : (1) petani maju, dan (2) petani berkembang. Petani maju adalah petani yang telah memanfaatkan teknologi Budidaya dengan baik. Sementara petani berkembang adalah petani yang masih menggunakan teknik bercocok tanam konvensional dalam kegiatan budidayanya.

Namun secara umum, untuk budidaya cabai merah di kawasan ini sudah menggunakan cara bercocok tanam yang mengadopsi penggunakan teknologi. Plastik mulsa dan pemilihan benih unggul sudah digunakan secara umum oleh petani, baik petani berkembang maupun petani maju.

Tabel 1. Jumlah petani dan luas lahan tanaman cabai di Kecamatan Ballik Bukit, Kabupaten Lampung Barat.

\begin{tabular}{|l|l|l|}
\hline Sifat petani & Jumlah petani (orang) & Luas lahan (ha) \\
\hline Petani kemitraan & 40 orang & 24 ha \\
\hline Petani gurem & 40 orang & 24 ha \\
\hline Jumlah & 80 orang & 48 ha \\
\hline
\end{tabular}

Sumber : Komunitas Internet Petani Liwa (KIPLA).

Berdasarkan uraian latar belakang di atas, maka dalam penelitian ini penulis tertarik untuk mengambil judul “ANALISIS PERBEDAAN PENDAPATAN PETANI CABAI KEMITRAAN INDOFOOD DENGAN PETANI GUREM DI KECAMATAN BALIK BUKIT, KABUPATEN LAMPUNG BARAT".

\section{Rumusan Masalah}

Berdasarkan identifikasi masalah diatas, maka dapat dirumuskan masalah dalam penelitian ini. Adapun rumusan masalahnya adalah "Apakah Terdapat Perbedaan Pendapatan Petani Cabai Kemitraan Indofood dengan Petani Gurem di Kecamatan Balik Bukit Kabupaten Lampung Barat?". 


\section{Tujuan Penelitian}

Untuk mengetahui dan menganalisis apakah ada perbedaan pendapatan antara petani cabai kemitraan Indofood dengan petani gurem di Kecamatan Balik Bukit, Kabupaten Lampung Barat.

\section{TINJAUAN PUSTAKA}

\section{Pengertian Pendapatan}

Menurut Skousen, dan Stice (2010:261) Pendapatan adalah arus masuk atau penyelesaian (atau kombinasi keduanya) dari pengiriman atau produk barang, memberikan jasa atau melakukan aktivitas lain yang merupakan aktivitas utama atau aktivitas pusat yang sedang berlangsung.

Pada hakikatnya pendapatan yang diterima oleh seseorang maupun badan usaha tentunya dipengaruhi oleh banyak faktor, seperti tingkat pendidikan dan pengalaman seorang, semakin tinggi tingkat pendidikan dan pengalaman maka makin tinggi pula tingkat pendapatanya, kemudian juga tingkat pendapatan sangat dipengaruhi oleh modal kerja, jam kerja, akses kredit, jumlah tenaga kerja, tanggungan keluarga, jenis barang dagangan (produk) dan faktor lainya. Pada umumnya masyarakat selalu mencari tingkat pendapatan tinggi untuk memenuhi kebutuhan rumah tangganya, akan tetapi dibatasi oleh beberapa faktor tersebut (Pitma, 2015:38).

Menurut Miller dalam Yuliani (2011: 33), ada berbagai faktor yang menjadi penyebab terjadinya perbedaan atau ketimpangan pendapatan. Faktor-faktor tersebut adalah :

1) Usia, pekerja muda biasanya masih terbatas keterampilan dan pengalamannya. Produk fisik marjinal mereka lebih rendah daripada rata-rata produk fisik marjinal yang dihasilkan oleh para pekerja yang lebih berumur dan berpengalaman.

2) Karakteristik bawaan, besarnya pendapatan kalangan tertentu besarnya sangat ditentukan oleh karakteristik bawaan mereka. Sejauh mana besar kecilnya pendapatan dihubungkan dengan karakteristik bawaan masih diperdebatkan, apalagi keberhasilan seseorang seringkali dipengaruhi oleh kondisi lingkungan dan masyarakatnya.

3) Keberanian mengambil resiko, mereka yang bekerja di lingkungan kerja yang berbahaya biasanya memperoleh pendapatan lebih besar. siapapun yang berani mempertaruhkan nyawanya dibidang kerja akan mendapatkan imbalan lebih besar.

4) Ketidapastian dan variasi pendapatan. Bidang-bidang kerja yang hasilnya serba tidak pasti, misalnya bidang kerja pemasaran, mengandung resiko yang lebih besar. Mereka yang menekuni bidang itu dan berhasil, akan menuntut dan menerima pendapatan yang lebih besar, melebihi mereka yang bekerja di bidangbidang yang lebih aman. 
5) Bobot latihan, bila karakteristik bawaan dianggap sama atau diabaikan, maka mereka yang mempunya bobot latihan yang lebih tinggi pasti akan memperoleh pendapatan yang lebih besar.

6) Kekayaan warisan, Mereka yang memiliki kekayaan warisan, atau lahir di lingkungan keluarga kaya akan lebih mampu memperoleh pendapatan daripada mereka yang tidak memiliki warisan, sekalipun kemampuan dan pendidikan mereka setara.

7) Ketidaksempurnaan pasar, monopoli, monopsoni, kebijakan sepihak serikat buruh, penetapan tingkat upah minimun oleh pemerintah, ketentuan syaratsyarat lisensi, sertifikat dan sebagainya, semuanya turut melibatkan perbedaan perbedaan pendapatan dikalangan kelas-kelas pekerja.

8) Diskriminasi, di pasar tenaga kerja sering terjadi diskriminasi ras, agama, atau jenis kelamin dan itu semua merupakan penyebab variasi tingkat pendapatan.

\section{Faktor-Faktor yang Mempengaruhi Hasil Produksi Usaha Pertanian}

Keberhasilan dalam melakukan usaha pertanian pada dasarnya di pengaruhi oleh beberapa faktor, baik yang berasal dari dalam atau luar pertanian. Dalam hal ini para ahli mengemukakan pendapat yang berbeda-beda tentang faktor-faktor yang menentukan keberhasilan dalam usaha pertanian.

Bidang pertanian produksi dipengaruhi berbagai macam faktor seperti luas lahan, bibit, pupuk, obat hama (pestisida), sistem irigasi, tenaga kerja, iklim dan sebagainya. Produksi akan menunjukan tingkat hasil dari kuantitas pertanian, menurunnya produksi dipengaruhi oleh berbagai hal salah satunya yaitu iklim dan pola curah hujan, penurunan produksi pertanian ini dikarenakan terjadinya penurunan luas lahan akibat dari dampak perubahan iklim. Perubahan iklim memiliki pengaruh negatif terhadap produksi pertanian (Utami, dkk.,2011).

Petani menyadari perubahan iklim khususnya curah hujan dan dampaknya terhadap produksi tanaman pangan telah mampu mengembangkan strategi mata pencaharian, serta adaptasi yang mereka lakukan dengan cara yang terus menerus bisa dilakukan untuk mengatasi dampak perubahan iklim yang tidak menentu terhadap produksi tanaman pangan (Ayunwuy, dkk., 2010 dalam Hidayati 2015).

Soejono, dkk. (2009) menyatakan bahwa faktor-faktor yang signifikan terhadap produksi adalah pupuk, obat-obatan dan tenaga kerja. Sedangkan faktor yang tidak signifikan berpengaruh terhadap produksi adalah luas lahan dan benih (Hidayati:2015)

Produksi/hasil pertanian dalam arti luas tergantung dari faktor genetik/varietas yang ditanam, lingkungan termasuk antara lain tanah, iklim dan teknologi yang dipakai. Sedangkan dalam arti sempit terdiri dari varietas tanaman, tanah, iklim, dan faktor- 
faktor non teknis seperti keterampilan petani, biaya/sarana produksi pertanian dan alat-alat yang digunakan (Nurmala,dkk : 2012).

Berikut faktor-faktor yang memberikan dampak signifikan terhadap hasil produksi tani :

a. Genetik

Salah satu peranan penting dari faktor genetik ialah kemampuan suatu tanaman hibrida (hasil silang dari induk-induk yang potensial ) untuk berpotensi tinggi. Potensi hasil tinggi beserta sifat-sifat lainnya (seperti mutu, ketahanan, serangan hama penyakit, kekeringan) berhubungan sangat erat dengan susunan genetika tanaman.

b. Alam Atau lingkungan

Alam atau lingkungan sangat besar pengaruhnya terhadap produksi suatu pertanian. Lingkungan atau alam ini didefinisikan sebagai rangkaian semua persayaratan atau kondisi yang dapat memberikan pengaruh terhadap kehidupan dan perkembangan tanaman.

c. Tenaga kerja

Setiap usaha pertanian yang akan dilaksanakan pasti membutuhkan tenaga kerja. Oleh karena itu, dalam analisis ketenagakerjaan di bidang pertanian, penggunaan tenaga kerja dinyatakan oleh besarnya curahan tenaga kerja. Curahan tenaga kerja yang dipakai adalah besar tenaga kerja efektif yang dipakai. Pengunaan tenaga kerja tidak lepas dari kegiatan usaha tani.

d. Modal

Faktor modal merupakan unsur dalam pertanian yang sangat penting sebab tanpa modal segalanya tidak berjalan. Modal dibedakan menjadi dua yaitu modal tetap dan modal berjalan. Modal tetap (tanah) tidak akan habis dalam satu kali pakai atau produksi. Sedangkan modal bergerak (uang tunai, pupuk, tanaman) dianggap habis untuk satu kali produksi. Modal bisa diperoleh atau berasal dari pemilik, warisan, atau kontrak (kredit).

e. Manajemen

Manajemen sangat penting peranannya apabila dikaitkan dengan efisiensi. Artinya walaupun faktor produksi tanah, pupuk, obat-obatan, tenaga kerja, dan modal merasa cukup, tetapi apabila tidak dikelola dengan baik maka produksi yang baik dan tinggi tidak akan tercapai. Manajemen diperlukan untuk efisiensi penggunaan modal, meliputi kemampuan untuk menentukan, mengorganisasi, mengordinir dan menghasilkan produk yang diharapkan. 


\section{Pengertian Usaha Kemitraan}

Kemitraan merupakan upaya yang melibatkan berbagai sektor, klompok masyarakat, lembaga pemerintah maupun bukan pemerintah, untuk berkerjasama untuk mencapai suatu tujuan bersama berdasarkan kesepakatan prinsip dan peran masing-masing, dengan demikian untuk membangun kemitraan harus memenuhi beberapa persyaratan yaitu persamaan perhatian, saling percaya dan saling menghormati, harus saling menyadari pentingnya kemitraan, harus ada kesepakatan misi, visi, tujun dan nilai yang sama, harus berpijak pada landasan yang sama dan kesedian untuk berkorban untuk mencapai tujuan yang diinginkan.

Kemitraan pada esensiasinya adalah suatu kerjasama formal antara individuindividu, kelompok-kelompok atau organisasi-organisasi untuk mencapai suatu tugas atau tujuan tertentu.

Menurut Sujana (2012:78) Kemitraan merupakan bentuk kerjasama dua orang atau lebih orang atau lembaga untuk berbagi biaya, resiko, dan manfaat dengan cara menggabungkan kompetensinya masing-masing.

Dapat disimpulkan bahwa pengertian Kemitraan merupakan upaya yang melibatkan berbagai sektor, kelompok masayarakat, lembaga pemerintah maupun bukan pemerintah, untuk bekerjasama dalam mencapai suatu tujuan bersama berdasarkan kesepakatan prinsip dan peran masing-masing, dengan demikian untuk membangun kemitraan.

\section{Pengertian Petani Kemitraan}

Berdasarkan keputusan Menteri Pertanian Nomor 944 Tahun 1997 juga menyebutkan bahwa kemitraan usaha merupakan usaha untuk membudidayakan kelompok mitra dalam pembangunan pertanian yang berorientasi agribisnis, bahwa untuk lebih meningkatkan kemitraan usaha perlu dinilai tingkat hubungan kemitraan usaha, sehingga dapat diketahui masalah dan peluang pengembangannya. Kemitraan usaha pertanian merupakan salah satu instrumen kerjasama yang mengacu pada terciptanya suasana keseimbangan, keselarasan, dan keterampilan yang di dasari saling percaya antar perusahaan mitra dan klompok melalui perwujudan sinergi kemitraan, yaitu terwujudnya hubungan yang saling mebutuhkan, saling menguntungkan, dan saling memperkuat hubungan kemitraanya guna memperoleh hasil yang di inginkan.

Dapat disimpulkan bahwa pengertian usaha kemitraan agribisnis adalah hubungan antara perusahaan mitra dengan kelompok usaha pertanian dalam membangun kerjasama untuk memperoleh hasil timbal balik yang telah disetujui. 


\section{Pengertian Petani Gurem}

Petani gurem didefinisikan sebagai rumah tangga pertanian yang mengusahakan lahan pertanian kurang dari 0.5 ha, badan pusat statistik (BPS). Sedangkan Menurut Dawam Raharjo: "petani gurem adalah petani yang memiliki lahan antara 0,1 sampai kurang dari 0,25 ha, petani kecil adalah mereka yang memiliki lahan antara 0,25 sampai kurang dari 0,5 Ha, petani sedang yaitu petani yang memiliki luas lahan 0,5 sampai kurang dari 2,1 ha, dan petani kaya yaitu petani yang mempunyai luas lahan garapan antara 2,0 sampai kurang dari 5,0 ha.

Pada tahun 2013, jumlah rumah tangga petani gurem di indonesia adalah 14.250.000 rumah tangga atau 55,53 \% dari total rumah tangga petani di indonsia, badan pusat statistik (BPS). Banyaknya petani yang meninggalkan ladangnya atau tetap bertani dengan hasil minimal yang menyebabkan muncuknya eksistensi petani gurem.

\section{Perbedaan Petani Kemitraan dan Petani Gurem}

Petani gurem maupun kemitraan memiliki beberapa kesamaan seperti tujuan yang ingin dicapai, teknik pembudidayaan tanaman dan jumlah modal yang relatif sama. Hal paling mendasar yang membedakan antara petani kemitraan dan petani gurem yaitu sebagai berikut :

\section{Sumber Modal}

Petani kemitraan memiliki pembagian modal ataupun dukungan modal dalam bentuk uang, lahan usaha, alat atau bahan yang bersumber dari perusahaan mitra, sedangkan modal petani gurem bersumber dari diri sendiri.

2. Keuntungan

Petani kemitraan membagi hasil keuntungan kepada perusahaan mitra dengan kesepakatan yang telah disetujui sedangkan petani gurem memperoleh hasil keuntungan secara keseluruhan.

\section{Jaminan Harga}

Petani kemitraan memiliki jaminan harga beli dari perusahaan mitra yang sedangkan petani gurem hanya mengacu pada harga pasar umum. Dengan kesepakatan tersebut, petani kemitraan diuntungkan jika terjadi penurunan harga. Namun, disaat terjadi kenaikan harga justru petani gurem yang diuntungkan.

4. Pengembangan Usaha

Dalam pengembangan usahatani, petani kemitraan mendapat dukungan dari perusahaan mitra untuk mengembangkan usahanya dalam bentuk pengetahuan melalui penyuluhan teknik bertani, pengetahuan varietas, pupuk, bibit bahkan informasi produk dan teknologi pertanian terkini. Petani gurem harus secara mandiri dan inisiatif dalam mengembangkan usahatani miliknya ataupun mendapat pengembangan serupa yang didapat petani mitra dari pemerintah atau pihak lainnya. 


\section{Kerangka Pikir}

Kegiatan usahatani cabai merah sebagai suatu proses produksi harus dilakukan secara efisien, sehingga diperoleh pendapatan yang maksimal. Identifikasi biaya dan penerimaan diperlukan dalam analisis pendapatan usahatani tersebut. Penerimaan yang diterima untuk setiap satuan unit biaya yang dikeluarkan dapat dihitung dengan pendekatan rasio $\mathrm{R} / \mathrm{C}$ yang dinilai layak jika hasil hitung lebih dari satu. Sehingga dapat diketahui sistem pertanian mana yang lebih berpotensi meningkatkan pendapatan antara petani gurem dan kemitraan Indofood. Bagan alur kerangka pemikiran tersebut dappat dilihat pada gambar 1.

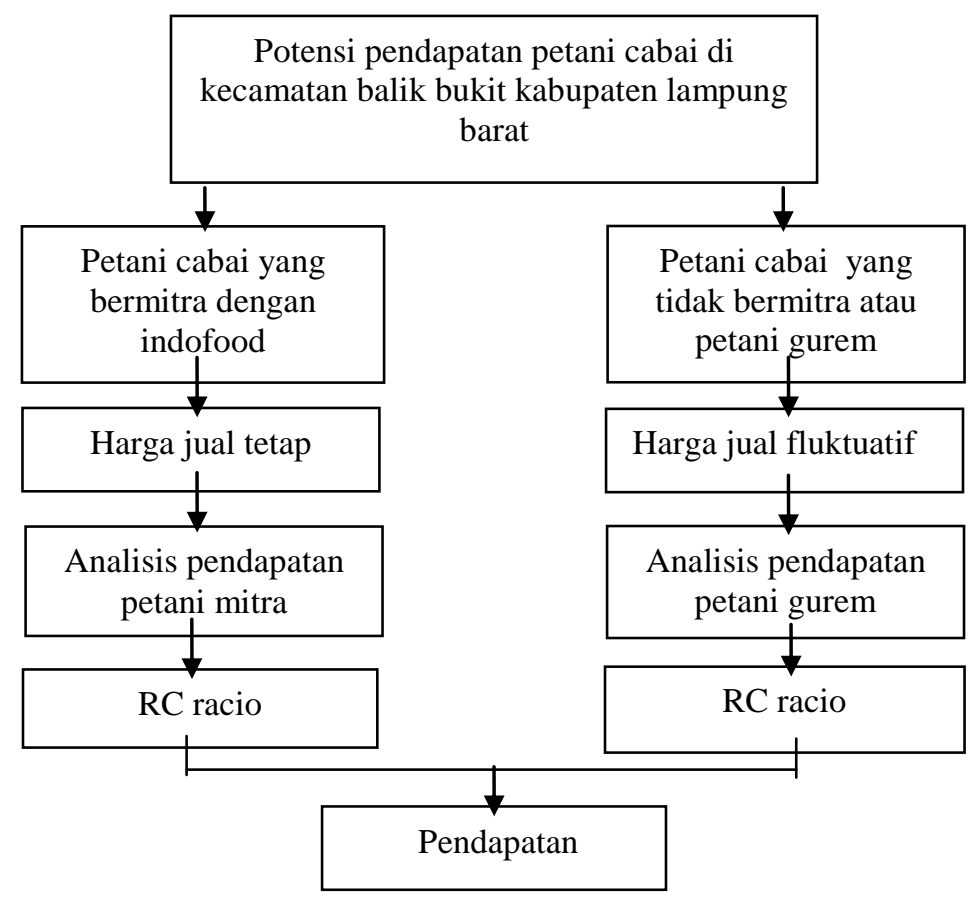

Gambar 1. Kerangka pemikiran analisis perbedaan pendapatan petani cabai kasus pada petani mitra indoofood dan petani gurem di kecamatan balik bukit Kabupaten Lampung Barat.

\section{Hipotesis}

- Hipotesis Alternatif (Ha) : “Ada perbedaan pendapatan antara petani cabai kemitraan Indofood dengan petani gurem di Kecamatan Balik Bukit Kabupaten Lampung Barat".

- Hipotesis Nol (Ho) : “Tidak ada perbedaan pendapatan antara petani cabai kemitraan Indofood demgan petani gurem di Kecamatan Balik Bukit Kabupaten Lampung Barat".

\section{METODE PENELITIAN}

Metode penelitian yang penulis gunakan adalah deskriptif kuantitatif yang ditentukan dengan cara menetapkan kriteria tertentu atau batasan berdasarkan kajian teoritis oleh penulis. 


\section{Lokasi dan Objek Penelitian}

Lokasi penelitian ini adalah Kecamatan Balik Bukit Kabupaten Lampung Barat.Sedangkan objek penelitiannya adalah petani dengan 28 petani kemitraan Indofood dan 28 petani gurem di Kecamatan Balik Bukit, Lampung Barat.

\section{Teknik Pengumpulan Data}

Dalam penelitian ini teknik yang digunakan adalah, wawancara, dan dokumentasi.

\section{Teknik Analisis Data}

Analisis data yang dilakukan meliputi metode analisis data kualitatif yang dipaparkan secara deskriptif pada analisis keragaan usahatani. metode analisis kuantitatif menggunakan analisis pendapatan usahatani dan analisis perbandingan penerimaan dan biaya (R/C Ratio) untuk mengetahui tingkat efisiensi usahatani komoditas cabai kemitraan Indofood dan gurem di Balik Bukit, Lampung Barat, kemudian untuk mengetahui perbedaan digunakan rumus Uji T dua sampel independen.

\section{HASIL DAN PEMBAHASAN}

Analisis Pendapatan Usaha Tunai

Pendapatan usaha tani adalah pendapatan yang diperoleh dari hasil produksi cabai dalam satu periode tanam dikalikan harga jual cabai pada periode tanam tersebut. Pendapatan dalam penelitian ini dibedakan menjadi dua, yakni pendapatan atas biaya tunai (pendapatan tunai) dan pendapatan atas biaya non tunai (pendapatan total). Pendapatan pertanian cabai per periode tanam 2018 adalah sebagai berikut:

Tabel 3. Pendapatan pertanian cabai per periode tanam 2018

\begin{tabular}{|l|l|l|l|l|}
\hline No & Jenis Petani & Panen (Kg) & Harga Jual (Rp) & Pendapatan Total (Rp) \\
\hline 1 & Mitra & 5.019 & 12.000 & 60.228 .000 \\
\hline 2 & Gurem & 4.552 & 8.000 & 36.416 .000 \\
\hline
\end{tabular}

Sumber : Data Primer diolah

Adapun rincian pendapatan atas biaya tunai dan pendapatan atas biaya non tunai sebagai berikut:

Tabel 4. pendapatan atas biaya tunai dan pendapatan atas biaya non tunai

\begin{tabular}{|l|l|c|c|}
\hline No & \multicolumn{1}{|c|}{ Uraian } & Mitra & Gurem \\
\hline 1 & Pendapatan Total & Rp. 60.228 .000 & Rp. 36.416 .000 \\
\hline 2 & Biaya Tunai & Rp. 45.880 .000 & Rp. 41.380 .000 \\
\hline 3 & Biaya Non Tunai & Rp. 660.000 & Rp. 460.000 \\
\hline 4 & Biaya Total & Rp. 46.540 .000 & Rp. 41.840 .000 \\
\hline 5 & Pendapatan atas biaya tunai & Rp. 14.348 .000 & Rp. -4.964 .000 \\
\hline 6 & Pendapatan atas biaya total & Rp. 13.688 .000 & Rp. -5.424 .000 \\
\hline
\end{tabular}

Sumber: Data primer diolah 
Dari tabel diatas diketahui bahwa keuntungan petani cabai yang bermitra dengan PT. Indofood jauh lebih besar daripada petani cabagi gurem. Bahkan petani cabai gurem mengalami kerugian yang sangat banyak, hal tersebut disebabkan harga cabai dipasaran pada periode tanam tahun 2018 sedang mengalami perununan yang cukup besar. Berbeda dengan dengan petani cabai kemitraan, mereka mendapat jaminan harga yang stabil dari PT. Indofood, sehingga petani cabai kemitraan tidak mengalami kerugian meskipun keuntungannya tidak terlalu besar.

Masing-masing dari kedua jenis petani tersebut memiliki keuntungan dan kerugian tersendiri. Petani cabai kemitraan diuntungkan ketika harga cabai dipasaran mengalami penurunan, karena petani cabai sudah menjalin kontrak harga dengan perusahaan mitra yakni PT. Indofood. Untuk petani gurem, mereka akan diuntungkan apabila harga cabai dipasaran sedang melambung tinggi sehingga keuntungan yang petani cabai gurem lebih besar. Namun sebaliknya, apabila harha cabai dipasaran sedang mengalami penurunan atau harga anjlok, maka petani gurem akan banyak mengalami kerugian seperti yang di alami pada periode tanam tahun 2018 yang sedang penulis teliti.

\section{Rasio R/C}

Rasio R/C atau Revenue Cost Ratio adalah perbandingan antara pengeluaran dan pendapatan, sehingga dapat diketahui usaha cabai ini layak dijalankan atau tidak. Pada penelitian ini, rasio $\mathrm{R} / \mathrm{C}$ dibagi menjadi dua, yakni rasio atas biaya tunai dan rasio atas biaya total. Rasio atas biaya tunai yakni membandingkan antara pendapatan total dengan biaya tunai dan rasio atas biaya total yakni membandingkan antara pendapatan total dengan biaya total.

Adapun rasio R/C dapat dilihat pada tabel berikut ini:

Tabel 5. Rasio R/C

\begin{tabular}{|l|l|c|c|}
\hline No & \multicolumn{1}{|c|}{ Uraian } & Mitra & Gurem \\
\hline 1 & R/C Rasio atas biaya tunai & 1.31 & 0.88 \\
\hline 2 & R/C Rasio atas biaya total & 1.30 & 0.87 \\
\hline
\end{tabular}

Sumber: Data primer diolah

Dari tabel di atas diketahui bahwa nilai R/C rasio petani cabai kemitraan lebih dari 1, artinya usaha tersebut layak untuk tetap dijalankan. Sedangkan $\mathrm{R} / \mathrm{C}$ rasio pada petani cabai gurem kurang dari 1, menunjukkan bahwa usaha tersebut tidak layak untuk dijalankan karena mengalami kerugian atau pendapatan minus.

Diketahui nilai R/C rasio atas biaya tunai petani cabai kemitraan sebesar 1.31 , hal tersebut menunjukkan bahwa Rp. 1 biaya tunai yang dikeluarkan akan mendapatkan pendapatan sebesar Rp. 1.31,-- Nilai R/C rasio atas biaya tunai petani gurem sebesar 0.88 , 
hal tersebut menunjukkan bahwa Rp. 1 biaya tunai yang dikeluarkan akan mendapatkan pendapatan sebesar Rp. 0.88,-. artinya petani cabai gurem mengalami kerugian sebesar Rp. 0,12 setiap kali Rp. 1 yang dikeluarkan.

Diketahui pula nilai $\mathrm{R} / \mathrm{C}$ rasio atas biaya total petani kemitraan sebesar 1.30 , hal tersebut menunjukkan bahwa Rp. 1 biaya total yang dikeluarkan akan mendapatkan pendapatan sebesar Rp. 1.30,-. Nilai R/C rasio atas biaya total petani gurem sebesar 0.87 , hal tersebut menunjukkan bahwa Rp. 1 biaya tunai yang dikeluarkan akan mendapatkan pendapatan sebesar Rp. 0.87,-. artinya petani cabai gurem mengalami kerugian sebesar Rp. 0,13 setiap kali Rp. 1 yang dikeluarkan.

\section{Uji T Dua Sampel}

Independent Samples Test

\begin{tabular}{|c|c|c|c|c|c|c|c|c|c|c|}
\hline & \multicolumn{2}{|c|}{$\begin{array}{c}\text { Levene's } \\
\text { Test for } \\
\text { Equality of } \\
\text { Variances }\end{array}$} & \multicolumn{7}{|c|}{ t-test for Equality of Means } \\
\hline & & \multirow[t]{2}{*}{$\mathrm{F}$} & \multirow[t]{2}{*}{ Sig. } & \multirow[t]{2}{*}{$\mathrm{t}$} & \multirow[t]{2}{*}{ df } & \multirow[t]{2}{*}{$\begin{array}{c}\text { Sig. } \\
(2- \\
\text { tailed } \\
)\end{array}$} & \multirow[t]{2}{*}{$\begin{array}{c}\text { Mean } \\
\text { Differen } \\
\text { ce }\end{array}$} & \multirow[t]{2}{*}{\begin{tabular}{|c|} 
Std. \\
Error \\
Differen \\
ce
\end{tabular}} & \multicolumn{2}{|c|}{$\begin{array}{c}95 \% \\
\text { Confidence } \\
\text { Interval of the } \\
\text { Difference } \\
\end{array}$} \\
\hline & & & & & & & & & Lower & Upper \\
\hline & $\begin{array}{l}\text { Equal } \\
\text { variances } \\
\text { assumed }\end{array}$ & 4,000 & 055 & $\begin{array}{r}14,00 \\
0\end{array}$ & 28 & 000 & $\begin{array}{r}1909200 \\
0,000\end{array}$ & $\begin{array}{r}1278482 \\
, 143\end{array}$ & $\begin{array}{r}15279 \\
898,04 \\
8\end{array}$ & $\begin{array}{r}205176 \\
01,952\end{array}$ \\
\hline Hasil & $\begin{array}{l}\text { Equal } \\
\text { variances } \\
\text { not } \\
\text { assumed }\end{array}$ & & & $\begin{array}{r}15,00 \\
0\end{array}$ & $\begin{array}{r}15,00 \\
0\end{array}$ & ,000 & $\begin{array}{r}1909200 \\
0,000\end{array}$ & $\begin{array}{r}1193250 \\
, 000\end{array}$ & $\begin{array}{r}15355 \\
397,83 \\
0\end{array}$ & $\begin{array}{r}204421 \\
02,170\end{array}$ \\
\hline
\end{tabular}

Sumber : Output SPSS 21

Berdasarkan output SPSS diatas diketahui bahwa nilai Sig. Levene's Test for Equality of Variances adalah sebesar $0.055>0.05$ maka dapat diartikan bahwa varian data antara pendapatan petani kemitraan dan petani gurem adalah homogen atau sama (Sujarweni, 2014:99). Sehingga penafsiran tabel output di atas berpedoman pada nilai yang terdapat dalam tabel Equal variances assumed.

Berdasarkan tabel output SPSS pada bagian Equal variances assumed diketahui nilai Sig. (2-tailed) sebesar $0.000<0.05$, Sehingga dapat diambil keputusan bahwa H0 yang menyatakan "Tidak ada perbedaan pendapatan antara petani cabai kemitraan Indofood dengan petani gurem di Kecamatan Balik Bukit Kabupaten Lampung Barat di tolak dan Ha yang menyatakan "Ada perbedaan pendapatan antara petani cabai kemitraan Indofood dengan petani gurem di Kecamatan Balik Bukit Kabupaten Lampung Barat dapat diterima". 
Dari tabel output diatas pada kolom "mean difference" diketahui nilainya sebesar 19092000, hal tersebut menunjukan bahwa perbedaan pendapatan antara petani kemitraan dan petani gurem sebesar Rp. 19.092.000.

\section{KESIMPULAN}

Hasil analisis pendapatan, diketahui bahwa petani cabai kemitraan mendapatkan keuntungan dan petani gurem mengalami kerugian. Hal tersebut terjadi karena harga cabai pada periode tanam tahun 2018 sedang mengalami penurunan atau harga anjlok. Hasil analisis $\mathrm{R} / \mathrm{C}$ rasio atas biaya tunai dan biaya total, $\mathrm{R} / \mathrm{C}$ rasio petani cabai kemitraan lebih dari 1 sehingga usaha tersebut layak untuk tetap dijalankan. Sedangkan R/C rasio petani cabai gurem kurang dari 1 yang berarti usaha tersebut tidak layak dijalankan karena akan mengalami kerugian.

Hasil uji T menunjukkan bahwa nilai Sig. (2-tailed) sebesar 0,00 dan lebih kecil dari $0,05(0.00<0.05)$ sehingga hipotesis $(\mathrm{Ha})$ yang menyatakan "Ada perbedaan pendapatan antara petani cabai kemitraan Indofood dengan petani gurem di Kecamatan Balik Bukit Kabupaten Lampung Barat” dapat diterima. Nilai mean diference sebesar 19092000, hal tersebut menunjukan bahwa perbedaan pendapatan antara petani kemitraan dan petani gurem sebesar Rp. 19.092.000.

\section{Saran}

Sebaiknya petani cabai gurem ikut bergabung dengan petani cabai kemitraan untuk menjalin kerjasama dengan PT. Indofood dikarenakan harga jual cabai yang ditawarkan oleh PT. Indofood jauh lebih stabil. Sehingga petani cabai gurem tidak mengalami kerugian.

\section{DAFTAR PUSTAKA}

Ahyari, Agus, 2011, Manajemen Produksi Perencanaan Sistem Produksi, Yogyakarta, BPFE.

Ari Kunto. 2013. Prosedur Penelitian : Suatu Pendekatan Praktik. Jakarta : Rineka Cipta.

Arikunto. 2011. Perosedur Penelitian Suatu Pendekatan Praktik. Jakarta : Rineka Cipta.

Assauri, Sofjan. 2016. Manajemen Operasi Produksi (Pencapaian Sasaran Organisasi Berkesinambungan). Edisi 3. PT. Raja Grafindo Persada. Jakarta.

Bukhori, M. 2014. Sektor Pertanian terhadap Pembangunan di Indonesia. Surabaya.

Darmadi, Hamid. 2013. Metode Penelitian Pendidikan dan Sosial. Bandung : Alfa Beta.

Gulo. 2010. Metodologi Penelitian. Grasindo. Jakarta.

http://iamalvian.blogspot.com/2012/10/makalah-kenaikan-harga_cabai_2673.html?m=1

http://nasional.sindonews.com/read/982789/161/nasib-petani-gurem-1427679967 
Ida Nurul Hidayati. 2015. Jurnal Ekonomi \& Studi Pembangunan. Http://journal.umy.ac.id. Di Akses Pada Jumat, 28 Juni 2019.

Imam Santoso. 2009. Akutansi Keuangan Menengah (Intermediate Accounting) Buku 2. PT. Refika Aditama, Bandung.

Mardalis. 2010. Metode Penelitian Suatu Pendekatan Proposal. Bumi Aksara, Jakarta.

Nurmala, Tati. 2012. Pengantar Ilmu Pertanian, Graha Ilmu, Yogyakarta.

Peraturan Menteri Pertanian Nomor. 944 Tahun 1997 Tentang Pedoman Penetapan Hubungan Kemitraan Usaha Pertanian.

Pitma Pertiwi. 2015. Analisi Faktor-Faktor Yang Mempengaruhi Pendapatan Tenaga Kerja Di Daerah Yogyakarta. Skripsi. Universitas Negeri Yogyakarta.

Sangadji, Etta Mamang dan Sopiah. 2010. Metodologi Penelitian. Graha Ilmu, Yogyakarta. Soejono, D., Sunarsih, M., dan Diantoro, K. (2009). Faktor-faktor yang mempengaruhi produksi padi pada kelompok tani Patemon II di Desa Patemon Kecamatan Tlogosari Kabupaten Bondowoso. J-SEP.Vol. 3

Soekarwati. 2006, Analisis Usahatani, Jakarta. Universitas Indonesia.

Stice, Stice, Skousen. 2010. Akutansi Keuangan, Buku 1 Edisi 16. PT. Raja Jakarta: Grafindo Persada, Jakarta.

Sugiono. 2010. Metode Penelitian Pendidikan Pendekatan Kuantitatif, Kualitatif, dan $R \& D$. Bandung : Alfabeta.

Sugiyono. 2014. Metodologi Penelitian Kuantitatif, Kualitatif, dan R\&D, CV Alfabeta, Bandung

Sujana, asep. ST., 2012. Manajemen Minimarket, Gerasindo, Jakarta.

Sumardjo, dkk., 2010. Teori dan Praktik Kemitraan Agribisnis, Penebar Swadaya, Jakarta.

Utami, Jamhari, dan Suhatmini Hardyastuti. (2011). El Nino, La Nina dan Penawaran Pangan di Jawa, Indonesia. Jurnal Ekonomi Pembangunan. Vol. 12: 2

Yuliani M. 2011. Analisis antara Keterkaitan Ekonomi dan Distribusi Pendapatan Studi Kasus 35 Kabupaten/Kota Di Jawa Tengah (2007-2008). Fakultas Ekonomi Universitas Dipenogoro Semarang. 